\title{
Impact of Landed Property Transformation on Reproductive Process in the Agrarian Process of Regions
}

\author{
E.I. Abdullina ${ }^{1}$, T.G. Mansurova ${ }^{2}$, A.N. Makarov³ , A.R. Nagimov ${ }^{4}$, \\ E.S. Khovanskaya ${ }^{5}$
}

\begin{abstract}
:
The article presents the results on land ownership transformation and its impact on the reproductive process in the agricultural sector of the Volga Region Federal District in conditions of the existing model.
\end{abstract}

The analysis of the consequences of the land reform, of which 115,4 million hectares of agricultural lands were transferred into common share ownership in the form of land shares without defining the boundaries on the ground, was carried out.

Availability of land shares which are not transformed into the land, fouls up and causes chaos and uncertainty in land relations, leading to the criminalization of the land market, speculative land transactions, hinders the development of the land turnover.

The position of the Volga Region Federal District and its individual regions in regard to the national indexes that characterize agricultural production, factors of reproduction, is established.

The conclusion concerning the low level of production profitability is made, and it hampers the extended reproduction and, consequently, the high demand for land for agricultural purposes in the future.

Keywords: Land, the land reform, transformation of land ownership, land shares, land relations, agricultural lands, reproduction process.

\footnotetext{
${ }^{I}$ Naberezhnye Chelny Institute of Kazan (Volga Region) Federal University, Russia.

${ }^{2}$ Naberezhnye Chelny Institute of Kazan (Volga Region) Federal University, Russia.

${ }^{3}$ Naberezhnye Chelny Institute of Kazan (Volga Region) Federal University, Russia.

${ }^{4}$ Naberezhnye Chelny Institute of Kazan (Volga Region) Federal University, Russia.

${ }^{5}$ Kazan Federal University, Kazan, Russia.
} 


\section{Introduction}

In all times the question of land ownership was the most painful for Russia. Domestic and foreign experience shows that the revival of Russia is possible only through the formation and development of the agricultural sector of the economy, as far as economic, social, political, cultural and historical aspects are intertwined in it. There are two ways to solve the question of land ownership in the history of the transformation of land relations of Russia. The first way - the evolutionary way was inherent to the reforms in 1861 and 1906. However, they were incomplete for a variety of subjective and objective reasons. These reforms were carried out by peaceful means, conditions for evolutionary transformation of small commodity peasant and feudal landlord economy into the commodity-capitalistic economy, based on labor co-operation, the use of science and technology were created. The second way - the revolutionary way - was typical for the reforms in 1917 and 1991, implemented by the nationalization of land in the first case, and in the second case through the destruction - especially of large, high-tech - industrial farming.

Nevertheless, the question of the decisive role of private land ownership in agrarian reforms and in efficiency improvement of domestic agricultural production was the basic postulate of the land reform. The program of the land reform on the territory of the Russian Federation, saying: "Implementation of the land reform would allow to transform land relations within households, to change the attitude to the land and enhance its productivity in them by the Decree of the Council of Ministers of the RSFSR \#30 from 18.01.1991, to create 80000 - 100000 peasant farms and to increase the production of agricultural products $1,5-1,8$ times", defined the expected results of the land reform exactly this way.

\section{Implementation of the land reform: Status of land shares}

In the process of implementation of the Decree of the President of the Russian Federation "On urgent measures for the implementation of the land reform in the RSFSR" from 27 December, 1991, the collectives state farms, other agricultural enterprises, collective farms and cooperatives that use the land on the basis of the permanent (perpetual) use, were prescribed to take a decision on the transition to the private and other forms of property, according to the current Land Code of the RSFSR (25 April, 1991) until 1 March, 1992 (within two months). It could sell the land plots in the following cases: retirement; receiving land by inheritance; relocation with the purpose to organize peasant farming on vacant lands of the redistribution fund; investment of the proceeds from the sale of land into the processing plants, trade, construction and service enterprises in rural areas (Blaug, 1997; Fleetwood, 1999; Hands, 2001).

According to the Decree of the Government of the Russian Federation "On the reorganization of collective and state farms" adopted immediately after the publication of the above-mentioned Decree, collective and state farms were 
recommended to hold reorganization within a year. Fixed and current assets (including the land) of these farms changed hands and were passed to their employees who became owners of the property and acquired the right for a free land and property share (in this case - according to the text of the Decree - the notion "land share" is used). At that the land share could be used in the following way: to get the land plot in order to set up the peasant farm, a private enterprise of repair services, construction, service, trade or another enterprise; to give the share to the partnership or joint-stock company, as well as to the cooperative society, as a constituent fee (contribution); to sell the share to other farmworkers or to the farm.

Because of this haste and thoughtless approach, a lot of villagers were demoralized, and, in some cases, they did not understand the nature of the land reform. And although most of the former workers of collective farms and state farms, farms pensioners, social workers (about 12 million villagers) got 115,4 million hectares, or $49 \%$ of agricultural lands, as their private ownership, in most cases there was no interest and motivation in effective work. There was the following situation in commercial agricultural land-use based on the above-mentioned regulations (Table $1)$.

Table 1. Status of land shares by the end of the 1990s

\begin{tabular}{|l|l|l|}
\hline & $\begin{array}{l}\text { Quantity, } \\
\text { thousand }\end{array}$ & $\%$ \\
\hline Registered owners of land shares & 11804,1 & 100,0 \\
\hline $\begin{array}{l}\text { Among them: } \\
\text { Passed the share for rent with the } \\
\text { corresponding contract; } \\
\begin{array}{l}\text { Passed the share to the authorized share } \\
\text { capital of the agricultural organization; }\end{array}\end{array}$ & 5016,2 & 42,5 \\
$\begin{array}{l}\text { Including with registration in constituent } \\
\text { documents; }\end{array}$ & 503,4 & 4,2 \\
$\begin{array}{l}\text { Right to use the share in the authorized share } \\
\text { capital of the agricultural organization; } \\
\begin{array}{l}\text { Including with registration in constituent } \\
\text { documents; }\end{array}\end{array}$ & 112,1 & 1,0 \\
$\begin{array}{l}\text { Got the land plot to expand the farm } \\
\text { household due to share }\end{array}$ & 1792,0 & 15,2 \\
\hline
\end{tabular}

At that moment not only the size of shares, but also the borders of land areas which they were in, were not identified. For this reason, until now it is difficult to implement the cadastral and state registration of citizens' rights for land plots (Weintraub, 1991; Gainova et al., 2013). As a result, over the last fifteen years 20,5 million hectares of land were allocated because of the land share (formed land plots) and registered as the private, state or municipal property (Table 2). The lands classified as agricultural land and owned by citizens, were consisted of land shares for $80,2 \%$ (94,9 mln. ha), including the unclaimed lands $(20,5 \mathrm{mln}$. ha), the owners of which did not receive the certificate within the prescribed time limit, or, having 
received them, did not exercise their rights of the land use. The total area of the land plots given for the ownership to (peasant) farms, for private farming, gardening, vegetable gardening, animal farming, individual housing and construction, agricultural production to sole proprietors was $19,5 \mathrm{mln}$. ha. The annual increase of this index was $1,3 \mathrm{mln}$. ha, and the number of land plots allocated to citizens because of the land share, increased for 957 thousand ha.

Table 2. Information on land shares in 1998-2012 (mln. ha)

\begin{tabular}{|l|l|l|l|}
\hline & 1998 & 2012 & $\begin{array}{l}1998 \text { to } \\
2012(+/-)\end{array}$ \\
\hline $\begin{array}{l}\text { Lands of the reorganized } \\
\text { agricultural enterprises } \\
\text { transferred to citizens } \\
\text { with ownership of the } \\
\text { land plot share: } \\
- \text { the total area of land } \\
\text { shares (mln. ha) } \\
- \text { citizens - owners of } \\
\text { land shares (mln.) }\end{array}$ & 115,4 & 94,9 & $-20,5$ \\
\hline
\end{tabular}

\section{Distribution of lands by forms of ownership on agricultural lands}

More than $87 \%$ of the lands owned by legal entities are the property of agricultural enterprises and organizations, 12\% - ownership of private (peasant) farms that were not re-registered as sole proprietors. On the lands of this category there are land plots bought out by privatized non-agricultural enterprises. For 1 January 2013 their area was 32800 ha. The land plots owned by non-commercial associations of citizens, occupied the area of 71800 ha.

Figure 1. Distribution of lands by forms of ownership on agricultural lands for 2006-2013 (thousand ha)

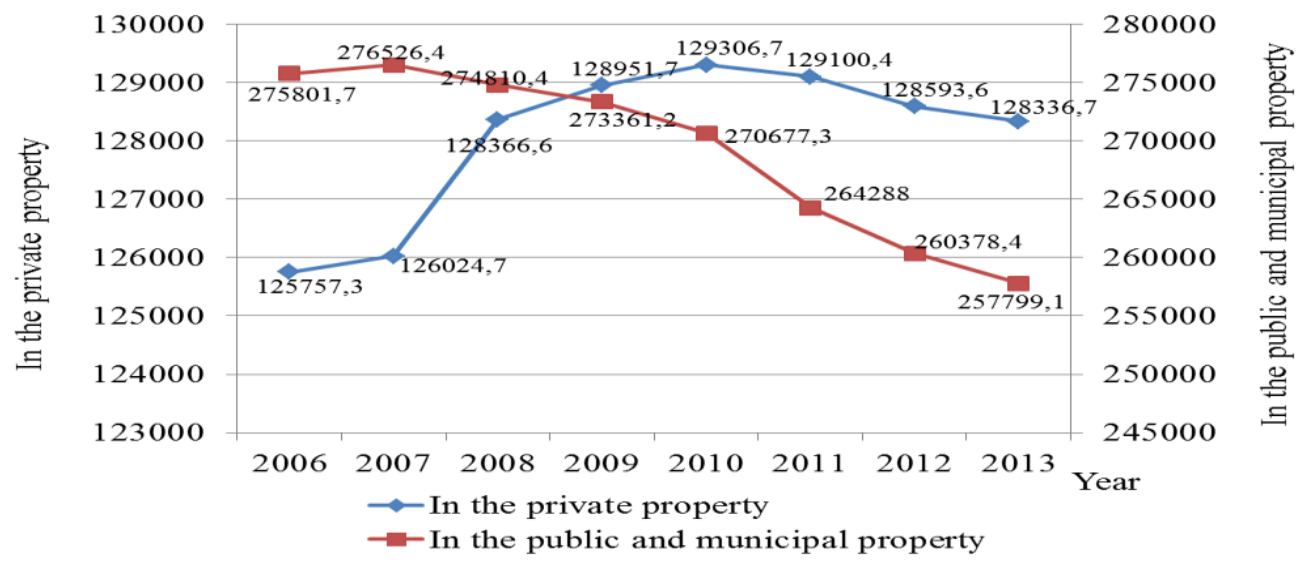


In Russia in the structure of private ownership of land there was reduction of lands owned by citizens, with the increase of the ownership of legal entities. Explanation of this is that one part of citizens implemented their rights of the land share owners, separating it in kind (formation of a land plot) with the following sale, the other part of citizens carried out - in accordance with the established procedure - the state registration of their share in the right of the common ownership of the land from agricultural lands and its subsequent sale to legal entities of the Russian Federation, or to the subject of the Russian Federation and municipalities (Glebova et al., 2013; Report on the status and use of agricultural land, 2013).

The current structure of land ownership leads to the situation that the land-use of legal entities (companies, organizations, enterprises, societies) involved in agricultural production, is based mainly on land shares of citizens; at the beginning of 2013 their share in used agricultural lands in the Russian Federation was 57\%.

Transformation of land relations formed the new structure of land ownership, and this caused changes in the reproduction process of the agricultural sector, as far as land resources became a deterrent for further development for innovatively active enterprises, which is very paradoxical - with large areas that are not used in the land production.

\section{Reproduction process in the agricultural sector of the Volga Region Federal District}

We will analyze the changes on the example of regions of the Volga Region Federal District. As far as the provision of an extended type of reproduction is the common concern for agricultural complex of any region, it allows for agricultural producers (as owners of the land) to gain - in addition to profit - extra income in the form of the land rent, and to increase tax capacity and create conditions for the development of rural areas at the regional and municipal levels (Mansurova and Abdullina, 2014).

In 2013, the agriculture of the Volga Region Federal District took the $2^{\text {nd }}$ place in the production in the Russian Federation among the federal districts with sharp differentiation of the production level among regions: The Republic of Tatarstan was on the $3^{\text {rd }}$ place, and the Kirov region was on the $44^{\text {th }}$ place. Growth rates of production are also different. In the current prices of 2005-2013 the national Russian growth index of the amount of agricultural production output was 2,7 times, and in the Republic of Tatarstan the increase was 2,6 times, and in the Kirov region - only 1,6 times (Isaeva et al., 2013; Regions of Russia. Socio-economic indicators. 2014).

Despite the implementation of the National program of agricultural development for 2008-2012, the implementation of a new national program for 2013-2020, reproduction problems in the industry remain very acute, as far as the mass of profit 
and the profitability level don't allow to provide the reproduction process of the extended type.

The balanced financial result allows to visualize the picture of crop and livestock production (Figure 2), which is calculated by the formula:

$$
\mathrm{P}_{\mathrm{r}}=\mathrm{TR}-\mathrm{TC}
$$

where $\operatorname{Pr}$ - profit;

$\mathrm{TR}$ - total revenue;

TC - aggregate costs.

Figure 2. Balanced financial result in the industries of crop and livestock production of the Volga Region Federal District in 2011-2013 (mln. rub.)

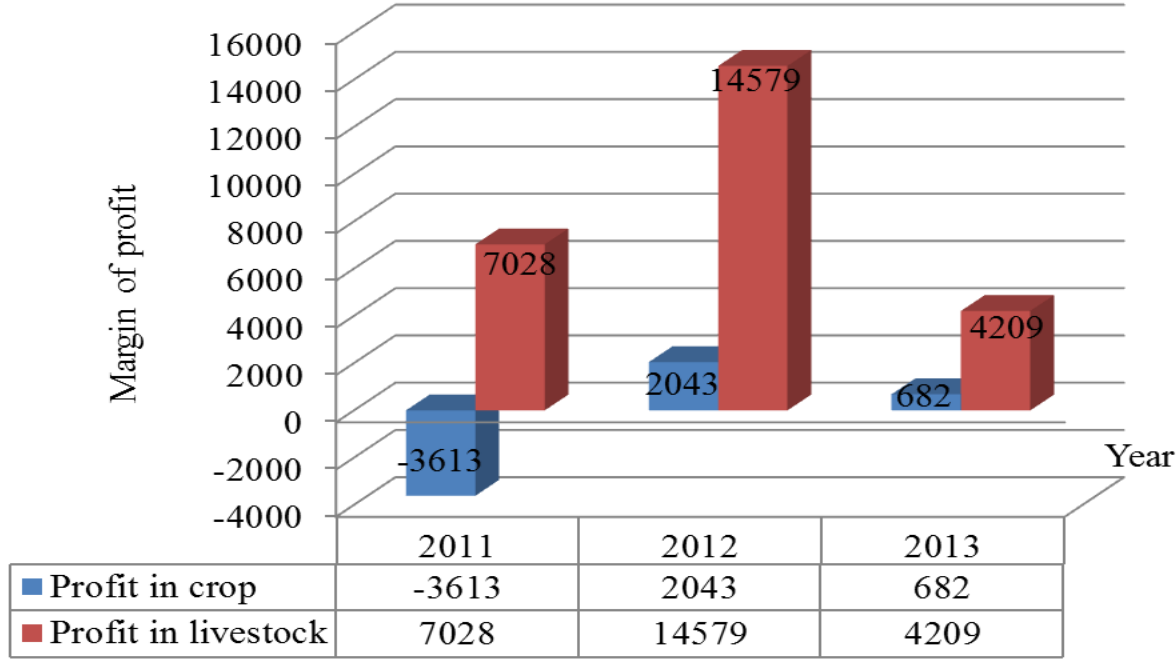

Based on the obtained balanced financial result we will calculate the sales profitability in the industries of crop and livestock production of the Volga Region Federal District (Table 3), using the following formula:

$$
\operatorname{ROS}=\frac{\mathrm{NI}}{\mathrm{NS}} \cdot 100 \%
$$

where ROS - sales profitability, \%;

$\mathrm{NI}$ - net profit, rub.;

NS - revenue from all kinds of sales, rub.

Table 3. Sales profitability in the industries of crop and livestock production of the Volga Region Federal District in 2011-2013 (\%)

\begin{tabular}{|l|l|l|l|}
\hline \multirow{2}{*}{ Indexes } & Years & \multicolumn{2}{|l|}{} \\
\cline { 2 - 4 } & 2011 & 2012 & 3 \\
\hline
\end{tabular}




\begin{tabular}{|l|l|l|l|}
\hline $\begin{array}{l}\text { Sales profitability in crop } \\
\text { production }\end{array}$ & 3,2 & 5,7 & 5,9 \\
\hline $\begin{array}{l}\text { Sales profitability in livestock } \\
\text { production }\end{array}$ & 3,5 & 6,5 & 1,4 \\
\hline
\end{tabular}

Based on the analysis of Table 3, we come to the conclusion that the dynamics of sales profitability in crop production of the Volga Region Federal District has a positive trend: in 2013 the increase - in comparison with 2012 - was $0,2 \%$, and in 2013 - in comparison with 2011 - was 2,5\%; however, analyzing this dynamics, we cannot say about the stable high growth rate. In the livestock industry there is the fall of sales profitability for $5,1 \%$, and it says about impossibility to provide the reproduction process of the extended type (Figure 3 ).

Figure 3. Dynamics of sales profitability in the industries of crop and livestock production of the Volga Region Federal District in 2011-2013, (\%)

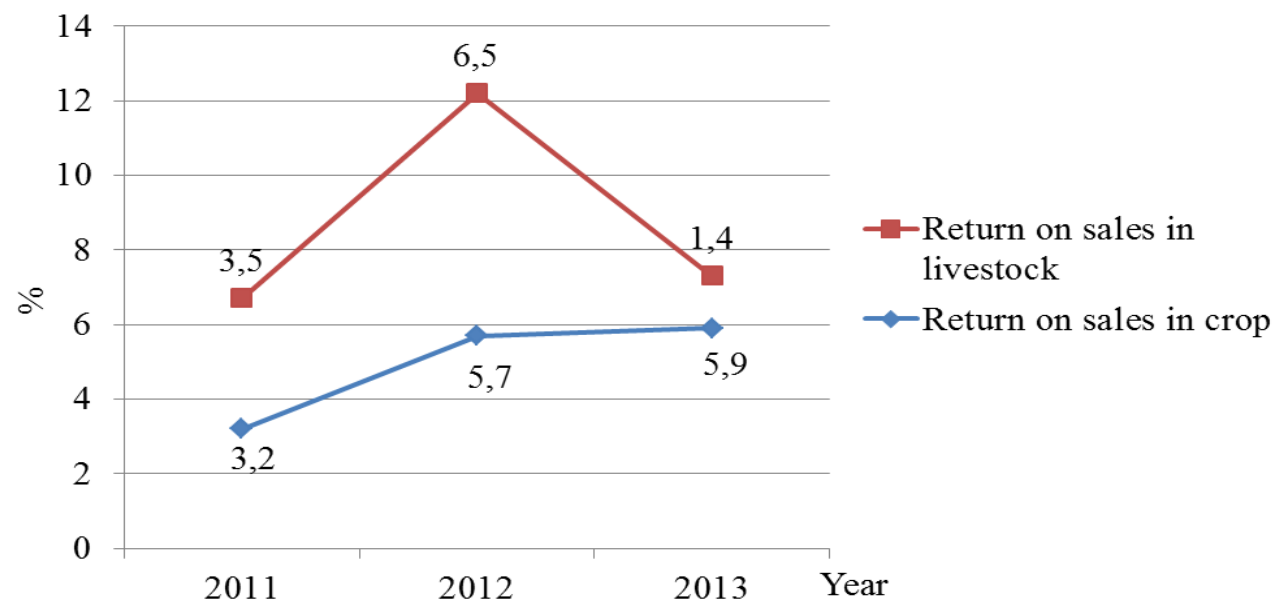

At that the main mass of profits in crop production (from 54 to 94\%) of the Volga Region Federal District is formed in the Saratov region, the Republic of Tatarstan and the Republic of Bashkortostan, in the livestock production (from 20 to 30\%) - in the Republic of Mari El, the Republic of Mordovia and the Kirov region. It is also necessary to say that the positive trend relating to the performance indicators of reproduction is seen in the sectors of agriculture of the Republic of Mari El, the Republic of Chuvashia and the Saratov region. In the Nizhny Novgorod region, the Orenburg region and the Perm region the crop and livestock production is unprofitable.

\section{Conclusions}

Availability of land shares that are not transformed into the land plots, which, in turn, are not registered as the ownership of definite economic entities with assignment of the cadastral number to the plots, causes chaos and uncertainty in land 
relations, leads to criminalization of the land market, speculative land transactions, restrains development of the land turnover. Unfavorable climate for investment is created in the areas with domination of the unclaimed land shares and ownerless lands, and local budgets lose substantial amounts of the land tax.

The results of the study of effects of the land ownership transformation on the example of the Volga Region Federal District showed that the institution of property does not automatically ensure the effectiveness of the agrarian economy and the stability of the reproduction process in agriculture. The low level of production profitability does not create prerequisites for extended reproduction, and, consequently, the high demand for land for agricultural purposes in the future.

Activation of the reproduction process in agriculture is possible based on changes in ownership for land in the direction of concentration of land areas in the ownership of immediate producers - agricultural enterprises and farms. It will contribute to reduction of areas of unclaimed land shares, to overcoming of the tendency of reduction of areas of the used agricultural farming lands.

\section{References:}

Allen, J. 1997. Economies of power and space. Geographies of Economies. London: Arnold, 59-70.

Battles, R.W., Robert C.Jr. and Thompson, R. C.Jr. 2000. Fundamentals of Agribusiness Finance, Blackwell Publishing.

Blaug, M. 1997. Economic Theory in Retrospect. Cambridge: Cambridge University Press.

Fleetwood, S. (Ed.) 1999. Critical Realism in Economics. Development and Debate. London and New York: Routledge.

Gainova, R.A., Shaidullin, R.N., Safiullin, L.N. and Maratkanova, E.M. 2013. Infrastructural Component in Maintenance of Competitiveness of Region. World Applied Sciences Journal, 27(13), 97-101.

Glebova, I.S., Sadyrtdinov, R. and Rodnyansky, D. 2013. Impact Analysis of Investment Attractiveness of the Republic of Tatarstan on Fixed Investments of its Leading Companies. World Applied Sciences Journal, 26(7), 911-916.

Hands, D.W. 2001. Reflection without Rules. Economic Methodology and Contemporary Science Theory, Cambridge (UK): Cambridge University Press.

Isaeva, T.N., Safiullin, L.N., Bagautdinova, L.N. and Shaidullin, R.N. 2013. Aspects of a multilevel study of competitive performance of objects and subjects of economic management. World Applied Sciences Journal, 27(13), 116-119.

Jeffrey, D.M. and Gerald, E.S. 2015. Land Tenure, Tenure Security and Farm Efficiency: Panel Evidence from the Philippines. Journal of Agricultural Economics, 66(1), 155-169.

Mansurova T.G., Abdullina E.I. 2014. Methodological approaches to assessing the impact of scientific and technological progress on the structure of social reproduction The Internet journal Naukovedenie, 5, 133-135. 
Mellor, J.W. 2008. Agricultural Development and Food Security. The Pakistan Development Review, 47(4).

Regions of Russia. Socio-economic indicators. 2014: P32 Stat. Sat / Rosstat, M., 900 p.

Report on the status and use of agricultural land / Ministry of Agriculture of the Russian Federation. M., 2013. - 61 p.

Weintraub, E.R. 1991. Stabilizing Dynamics: Constructing Economic Knowledge. New York: Cambridge University Press. 